\title{
Contribution of Osmotically Dehydrated Wild Garlic on Biscuits' Quality Parameters
}

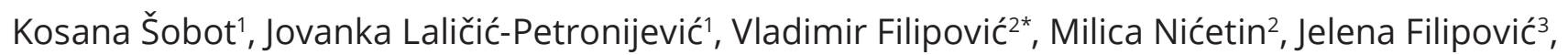 \\ Ljiljana Popović ${ }^{2}$
}

\footnotetext{
${ }^{1}$ Department of Food Technology, Faculty of Agriculture, University of Belgrade, Nemanjina 6, 11080 Belgrade - Zemun, Serbia

2 Department of Chemical Engineering, Faculty of Technology, University of Novi Sad, Bulevar cara Lazara 1, 21101 Novi Sad, Serbia

${ }^{3}$ Scientific Insitute of Food Technology, University of Novi Sad, Bulevar cara Lazara 1, 21101 Novi Sad, Serbia

* Corresponding author, e-mail: vladaf@uns.ac.rs
}

Received: 08 October 2018, Accepted: 12 December 2018, Published online: 08 April 2019

\begin{abstract}
Wild garlic generally improves strengths and regenerates the body and also helps in the treatment of various diseases. In this study the contribution of wild garlic osmotic dehydration process in sugar beet molasses on biscuits' quality parameters is investigated. Presented results showed that addition of osmotically dehydrated wild garlic in molasses impoved textural characteristics of biscuits by lowering hardness and increasing fracturability and also changed colour characteristics of biscuits. Chemical composition of biscuits with added osmotically dehydrated wild garlic was improved in comparison to the biscuits with added fresh wild garlic, where proteins, total sugars, celulose and ash compositions were increased in amounts of 1.86, 3.2, 15.8 and 5.76 \% respectively. Addition of osmodehydrated wild garlic had provided higher Zn, Cu and Fe biscuits' content in comparison to the addition of fresh wild garlic, in amounts of $2.75,15.33$ and $15.84 \%$ respectively. Developed mathematical models of biscuits quality parameters were statistically significant, while predicted and observed responses corresponded very well. In effort of obtaining new types of products, new application of known ingredients was proposed, allowing incorporation of sugar beet molasses' rich nutrient content in wheat products formulation.
\end{abstract}

Keywords

wild garlic, osmotic dehydration, sugar beet molasses, biscuits

\section{Introduction}

Wild garlic (Allium ursinum L.), is very often used as a traditional medicine, acting as the body strength improver and regenerator. It also helps in the treatment of diseases of the cardiovascular system, gastrointestinal tract or skin infections. Its flavor is more delicate compared to agriculture garlic. Culinary uses of the wild garlic are limited mainly to use the leaves. They can be used as raw, pickled, salted or in brine with oil and added to salads, soups, potatoes, cabbage, stewed vegetables and meat dishes [1,2].

There is no literature data regarding processed wild garlic addition in wheat products and no data regarding nutritive and physical characteristics of these types of products.

Oregano (Origanum vulgare) has been traditionally used in Mediterranean countries since antiquity, as a natural conservative and food spice. Oregano has antibacterial and antioxidant activity as versatile functional food ingredients giving above mentioned benefits on human health [3]. Oregano can be used as natural preservative for food [4].
Osmotic dehydration is important food preservation method in food processing industry due to many advantages considering mild processing temperatures, base waste materials and low energy requirements [5].

Sugar beet molasses is an alternative medium for osmotic dehydration, with the advantages of high dry matter (80\%) and specific nutrient content [6]. Osmodehydrated biological materials are more stable during storage than untreated due to lowered water activity values, via water loss in the osmotic dehydration process [7].

Biscuits are popular food or snack products consumed by many people, as a result of their varied taste, long shelf life and relatively low cost [8]. Biscuits could represent a potential candidate for the addition of functional ingredients, but their nutritional profile has to be improved in view of formulating functional products [9].

The main challenges of food producers are to produce food enriched with some functional ingredients in the way 
that it does not reduce their current quality despite the added active ingredient [10]. The main factors that have to be considered are the variations affecting the processing conditions, the sensory properties and the nutritional value of the final product $[9,11]$.

Addition of wild garlic and oregano enriches the flavor of biscuit products concurrently providing functional components to the biscuit formulation.

Since there is no available data regarding addition of osmotically dehydrated wild garlic to the biscuits, the goal of this research is to investigate the contribution of wild garlic osmotic dehydration process in sugar beet molasses on biscuits' quality parameters of texture, color, chemical and mineral composition in effort to obtain new type of wheat products enriched with different functional components.

\section{Experimental}

In this experimental investigation following materials were used: wild garlic (Allium ursinum) and dry oregano were purchased at local market, just before use; sugar beet molasses, was obtained from the sugar factory Crvenka, Serbia; spelt flour, grown in the year 2017 in Serbia.

$\mathrm{NaCl}$ produced by "SO Produkt", Stara Pazova, Serbia; sugar produced by "Šajkaška" Žabalj, Serbia; margarine produced by "AD Dijamant", Zrenjanin, Serbia; $\mathrm{NaHCO}_{3}$, produced by "Aleva", Novi Kneževac, Serbia, all were purchased from a local food market.

\subsection{Osmotic Dehydration Process}

Initial moisture content of the fresh wild garlic was 92.54 $\pm 0.66 \%$. Before the osmotic treatment, wild garlic leaves, were washed with running water, dried with paper towels and cut into squares, dimensions of $1 \times 1 \mathrm{~cm}$. Sugar beet molasses, had initial dry matter content of $85.04 \%$. Osmotic dehydration process was performed in laboratory vessels at temperature of $20^{\circ} \mathrm{C}$ under atmospheric pressure, at constant temperature chamber (Memmert IN160, Germany). The sample (leaves of wild garlic) to osmotic solution (sugar beet molasses) ratio of 1:20 (weight / weight) was used, to reduce excessive solution dilution. Wild garlic samples were immersed in molasses and stirred every 15 minutes for the purpose of better molasses homogenization with the diffused water from the wild garlic samples. After duration of the process of 4 hours, wild garlic samples were taken out from molasses to be lightly washed with water and gently blotted to remove excessive water. Final dry matter content of osmotically dehydrated wild garlic in molasses was $57.50 \pm 1.14 \%$.

\subsection{Biscuits preparation}

Biscuits were prepared according to modified AACC 10-50D [12] method, with following ingredients for biscuits with basic formulation: spelt flour, margarine, sugar, $\mathrm{NaCl}, \mathrm{NaHCO}_{3}$ and water in quantities of: $225 \mathrm{~g}, 64 \mathrm{~g}$, $2.25 \mathrm{~g}, 2.1 \mathrm{~g}, 2.5 \mathrm{~g}$ and $50 \mathrm{~g}$, respectively. Full experimental plan that included addition of fresh and osmotically dehydrated wild garlic and oregano to the basic biscuits formulation is presented in Table 1.

Quantities of added fresh and osmotically dehydrated wild garlic and oregano are chosen to allow maximal addition to biscuits formulation without disrupting dough structure. Fresh and osmotically dehydrated wild garlic are added in the quantities that are equal in their dry matter, allowing comparison at corresponding levels of addition. In biscuits formulation of samples where fresh or osmotically dehydrated wild garlic is added, quantity of water was reduced, for the quantity of water originating from fresh or osmotically dehydrated wild garlic, so the total amount of water presented in all dough formulations was the same. Weighted ingredients without water were placed in mixer bowl and mixed during 3 minutes, then water was added and dough was mixed during 2 minutes.

Table 1 Experimental plan of biscuits formulation with addition of fresh and osmotically dehydrated wild garlic and oregano

\begin{tabular}{|c|c|c|c|c|}
\hline Sample number & \multicolumn{2}{|c|}{ Quantity of wild garlic } & \multicolumn{2}{|c|}{ Quantity of oregano } \\
\hline \multicolumn{5}{|l|}{ Fresh } \\
\hline 1 & $0 \% *$ & $0 \mathrm{~g}^{*}$ & $0 \% *$ & $0 \mathrm{~g}^{*}$ \\
\hline 2 & $1.25 \%$ & $4.88 \mathrm{~g}$ & $0 \%$ & $0 \mathrm{~g}$ \\
\hline 3 & $2.5 \%$ & $9.76 \mathrm{~g}$ & $0 \%$ & $0 \mathrm{~g}$ \\
\hline 4 & $0 \%$ & $0 \mathrm{~g}$ & $0.5 \%$ & $1.13 \mathrm{~g}$ \\
\hline 5 & $1.25 \%$ & $4.88 \mathrm{~g}$ & $0.5 \%$ & $1.13 \mathrm{~g}$ \\
\hline 6 & $2.5 \%$ & $9.76 \mathrm{~g}$ & $0.5 \%$ & $1.13 \mathrm{~g}$ \\
\hline 7 & $0 \%$ & $0 \mathrm{~g}$ & $1 \%$ & $2.25 \mathrm{~g}$ \\
\hline 8 & $1.25 \%$ & $4.88 \mathrm{~g}$ & $1 \%$ & $2.25 \mathrm{~g}$ \\
\hline 9 & $2.5 \%$ & $9.76 \mathrm{~g}$ & $1 \%$ & $2.25 \mathrm{~g}$ \\
\hline \multicolumn{5}{|c|}{ Osmotically dehydrated } \\
\hline 10 & $0 \% *$ & $0 \mathrm{~g}^{*}$ & $0 \% *$ & $0 \mathrm{~g} *$ \\
\hline 11 & $1.25 \%$ & $4.88 \mathrm{~g}$ & $0 \%$ & $0 \mathrm{~g}$ \\
\hline 12 & $2.5 \%$ & $9.76 \mathrm{~g}$ & $0 \%$ & $0 \mathrm{~g}$ \\
\hline 13 & $0 \%$ & $0 \mathrm{~g}$ & $0.5 \%$ & $1.13 \mathrm{~g}$ \\
\hline 14 & $1.25 \%$ & $4.88 \mathrm{~g}$ & $0.5 \%$ & $1.13 \mathrm{~g}$ \\
\hline 15 & $2.5 \%$ & $9.76 \mathrm{~g}$ & $0.5 \%$ & $1.13 \mathrm{~g}$ \\
\hline 16 & $0 \%$ & $0 \mathrm{~g}$ & $1 \%$ & $2.25 \mathrm{~g}$ \\
\hline 17 & $1.25 \%$ & $4.88 \mathrm{~g}$ & $1 \%$ & $2.25 \mathrm{~g}$ \\
\hline 18 & $2.5 \%$ & $9.76 \mathrm{~g}$ & $1 \%$ & $2.25 \mathrm{~g}$ \\
\hline
\end{tabular}

* Quantities of added fresh and osmotically dehydrated wild garlic and oregano are expressed as percent of their dry matter on flour basis and in $g$ of dry matter. 
Obtained dough was rounded and placed in refrigerator at $8^{\circ} \mathrm{C}$ during 30 minutes for resting. Rested dough was laminated to uniform height of $7 \mathrm{~mm}$ and cut out to uniform size of $\varnothing 60 \mathrm{~mm}$. Formed dough was placed in a preheated oven at $200{ }^{\circ} \mathrm{C}$ and baked 10 minutes. Baked biscuits were left for cooling and resting at controlled ambient conditions $\left(23{ }^{\circ} \mathrm{C}\right.$ and relative humidity of $60 \%$ ) during 24 hours before further testing.

\subsection{Texture instrumental analysis of biscuits}

Biscuits texture was determined on a texture analyzer TA-XT plus (Stable Micro System, England) equipped with a $30-\mathrm{kg}$ load cell. Three-point bending test was used. Biscuit samples were placed on supports with a $12 \mathrm{~mm}$ gap length. The cross head speed was $3 \mathrm{~mm} / \mathrm{s}$ and travel distance $10 \mathrm{~mm}$. Maximum force and distance at break were registered as well as represented indicators of biscuit hardness and fracturability. Each measurement was performed in six replications.

\subsection{Color analysis of biscuits}

Color attributes were measured instrumentally using a Chroma meter (CR-400, Konica, Minolta, Tokyo, Japan) tri-stimulus colorimeter. The results were expressed in terms of $L^{*}$ - brightness (from 0 (black) to 100 (white)), $a^{*}$ - greenness / redness (from $-a^{*}$ (green) to $+a^{*}$ (red)), $b^{*}$ - blueness / yellowness (from $-b^{*}$ (blue) to $+b^{*}$ (yellow)) as per CIELab system. The measurements were observed under constant lighting conditions, using a white control $\left(L^{*}=98.76, a^{*}=-0.04, b^{*}=2.01\right)$ [13]. Each measurement was performed in six replications.

\subsection{Chemical composition of biscuits}

Proximate composition of biscuits was performed in accordance with standard AOAC [14] methods- protein (method No. 950.36), fat (method No. 935.38), cellulose (method No. 973.18), starch content (method No. 996.11), reducing sugars (method No. 80-68), ash (method No. 930.22) and water content (method No. 926.5). Each measurement was performed in six replications.

\subsubsection{Mineral composition analysis of biscuits}

Mineral content - calcium $(\mathrm{Ca})$, zinc $(\mathrm{Zn})$, copper $(\mathrm{Cu})$, magnesium $(\mathrm{Mg})$, iron $(\mathrm{Fe})$ and potassium $(\mathrm{K})$, of biscuits was determined following the standard methods described by AOAC [14]. Minerals were determined by atomic absorption spectrophotometry (method No. 984.27) on a Varian Spectra AA 10 (Varian Techtron
Pty Ltd., Mulgvare Victoria, Australia). Each measurement was performed in six replications.

\subsection{Statistical analysis}

Response Surface Methodology (RSM) was selected to estimate the main effect of the osmotically dehydrated wild garlic and oregano addition on biscuits quality parameter responses.

The accepted experimental design was according to Box and Behnken's [15] full factorial design. The independent variables were quantity of wild garlic $\left(X_{1}\right)$ of $0 \%$, $1.25 \%$ and $2.5 \%$ and oregano $\left(X_{2}\right)$ of $0 \%, 0.5 \%$ and $1 \%$. The observed dependent variables were the biscuits quality parameter responses: Hardness $\left(Y_{1}\right)$, Fracturability $\left(Y_{2}\right)$, of texture instrumental analysis; Brightness $\left(L^{*}\right)\left(Y_{3}\right)$, Share of greenness / redness $\left(a^{*}\right)\left(Y_{4}\right)$, Share of blueness / yellowness $\left(b^{*}\right)\left(Y_{5}\right)$ of color instrumental analysis; Proteins $\left(Y_{6}\right)$, Starch $\left(Y_{7}\right)$, Total sugars $\left(Y_{8}\right)$, Cellulose $\left(Y_{9}\right)$, Lipids $\left(Y_{10}\right)$, $\operatorname{Ash}\left(Y_{11}\right)$ of chemical content; and $\mathrm{Zn}\left(Y_{12}\right), \mathrm{Cu}\left(Y_{13}\right), \operatorname{Mg}\left(Y_{14}\right)$, $\mathrm{Ca}\left(Y_{15}\right), \mathrm{Fe}\left(Y_{16}\right), \mathrm{K}\left(Y_{17}\right)$ of mineral content. A model was fitted to the response surface generated by the experiment. The model used was function of the variables:

$Y_{k}=f_{k}$ (quantity of wild garlic, quantity of oregano) .

The following second order polynomial (SOP) model was fitted to the data. Models of the following form were developed to relate seventeen responses $\left(Y_{k}\right)$ to two process variables $\left(X_{i}\right)$ :

$Y_{k}=\beta_{k 0}+\sum_{i=1}^{2} \beta_{k i} X_{i}+\sum_{i=1}^{2} \beta_{k i i} X_{i}^{2}+\beta_{k 12} X_{1} X_{2} \quad k=1-17$

where: $\beta_{k 0}, \beta_{k i}, \beta_{k i i}$ and $\beta_{k 12}$ are constant regression coefficients; $Y$ are biscuits quality parameter responses; $X$, are quantities of wild garlic and oregano.

Analysis of variance (ANOVA) and RSM were performed using StatSoft Statistica, for Windows, ver. 10 program [16]. The model was obtained for each dependent variable (or response) where factors were rejected when their significance level was less than $95 \%$.

\section{Results and discussion}

Instrumental and color analysis of biscuits' texture is shown in Table 2. From consumers' point of view, texture is an important biscuit quality parameter determined by the application of breakage force [17]. In this work hardness of biscuit with wild garlic and oregano varied between 5930.26 \pm 102.64 and $4071.82 \pm 90.64 \mathrm{~g}$ (Table 1). The minimum hardness was obtained for sample 18, and maximum was 
Table 2 Texture and color instrumental analysis of biscuits with osmotically dehydrated wild garlic and oregano

\begin{tabular}{|c|c|c|c|c|c|}
\hline \multirow{2}{*}{ Sample number } & \multicolumn{2}{|c|}{ Texture instrumental analysis } & \multicolumn{3}{|c|}{ Color instrumental analysis } \\
\hline & Hardness $[\mathrm{g}]$ & Fracturability [mm] & $L^{*}$ & $a^{*}$ & $b^{*}$ \\
\hline 1 & $5930.26 \pm 202.64^{\mathrm{a}}$ & $1.21 \pm 0.15^{\mathrm{a}}$ & $67.43 \pm 0.54^{\mathrm{a}}$ & $7.68 \pm 0.61^{\mathrm{a}}$ & $24.96 \pm 0.31^{\mathrm{a}}$ \\
\hline 2 & $5052.53 \pm 109.35^{g}$ & $1.97 \pm 0.29^{b}$ & $66.64 \pm 0.19^{\mathrm{ab}}$ & $1.91 \pm 0.54^{\mathrm{d}}$ & $26.37 \pm 0.20^{b-d}$ \\
\hline 3 & $4577.94 \pm 117.60^{c-g}$ & $2.26 \pm 0.20^{\text {b-e }}$ & $64.84 \pm 0.35^{\mathrm{cd}}$ & $-0.64 \pm 0.13^{\mathrm{f}-\mathrm{i}}$ & $28.05 \pm 0.09^{\mathrm{fh}}$ \\
\hline 4 & $5909.84 \pm 178.00^{\mathrm{a}}$ & $1.25 \pm 0.23^{\mathrm{a}}$ & $65.48 \pm 0.37^{\mathrm{bc}}$ & $5.73 \pm 0.50^{\mathrm{b}}$ & $25.49 \pm 0.22^{\mathrm{ab}}$ \\
\hline 5 & $4863.6 \pm 235.04^{\mathrm{d}-\mathrm{g}}$ & $2.19 \pm 0.10^{b-d}$ & $65.56 \pm 0.29^{\mathrm{bc}}$ & $1.01 \pm 0.20^{\mathrm{de}}$ & $26.91 \pm 0.33^{\mathrm{ce}}$ \\
\hline 6 & $4416.26 \pm 135.70^{\text {b-e }}$ & $2.47 \pm 0.16^{\mathrm{b}-\mathrm{f}}$ & $63.85 \pm 0.41^{\mathrm{de}}$ & $-1.09 \pm 0.09^{\mathrm{h}-\mathrm{j}}$ & $28.94 \pm 0.41^{\mathrm{h}-\mathrm{i}}$ \\
\hline 7 & $5858.38 \pm 104.53^{\mathrm{a}}$ & $1.32 \pm 0.13^{\mathrm{a}}$ & $64.64 \pm 0.31^{\text {cd }}$ & $3.98 \pm 0.42^{\mathrm{c}}$ & $25.99 \pm 0.11^{\mathrm{a}-\mathrm{c}}$ \\
\hline 8 & $4713.52 \pm 184.19^{\mathrm{c}-\mathrm{g}}$ & $2.24 \pm 0.09^{\mathrm{b}-\mathrm{e}}$ & $63.76 \pm 0.81^{\mathrm{de}}$ & $0.50 \pm 0.04^{\mathrm{ef}}$ & $27.09 \pm 0.41^{\mathrm{d}-\mathrm{f}}$ \\
\hline 9 & $4381.77 \pm 144.75^{\mathrm{b}-\mathrm{e}}$ & $2.70 \pm 0.19^{\mathrm{d}-\mathrm{g}}$ & $62.24 \pm 0.11^{\mathrm{fg}}$ & $-1.90 \pm 0.34^{\mathrm{ik}}$ & $29.24 \pm 0.39^{\mathrm{ij}}$ \\
\hline 10 & $5930.26 \pm 102.64^{a}$ & $1.21 \pm 0.15^{\mathrm{a}}$ & $67.43 \pm 0.54^{\mathrm{a}}$ & $7.68 \pm 0.61^{\mathrm{a}}$ & $24.96 \pm 0.31^{\mathrm{a}}$ \\
\hline 11 & $4948.17 \pm 146.72^{\mathrm{fg}}$ & $2.32 \pm 0.20^{\mathrm{b}-\mathrm{f}}$ & $64.48 \pm 0.21^{\mathrm{cd}}$ & $0.98 \pm 0.50^{\mathrm{de}}$ & $27.26 \pm 0.52^{\mathrm{d}-\mathrm{f}}$ \\
\hline 12 & $4366.49 \pm 155.58^{\mathrm{b}-\mathrm{d}}$ & $2.69 \pm 0.11^{\mathrm{e}-\mathrm{g}}$ & $62.51 \pm 0.30^{\mathrm{e}-\mathrm{g}}$ & $-1.76 \pm 0.27^{i-k}$ & $28.46 \pm 0.30^{g-i}$ \\
\hline 13 & $5909.84 \pm 178.00^{\mathrm{a}}$ & $1.25 \pm 0.23^{\mathrm{a}}$ & $65.48 \pm 0.37^{\mathrm{bc}}$ & $5.73 \pm 0.50^{\mathrm{b}}$ & $25.49 \pm 0.22^{\mathrm{ab}}$ \\
\hline 14 & $4706.72 \pm 130.82^{\mathrm{c}-\mathrm{g}}$ & $2.38 \pm 0.24^{\mathrm{b}-\mathrm{f}}$ & $63.85 \pm 0.48^{\mathrm{de}}$ & $0.05 \pm 0.02^{\mathrm{e}-\mathrm{h}}$ & $27.81 \pm 0.27^{\mathrm{e}-\mathrm{g}}$ \\
\hline 15 & $4213.52 \pm 184.19^{\mathrm{bc}}$ & $2.80 \pm 0.10^{\mathrm{e}-\mathrm{g}}$ & $60.59 \pm 0.51^{\mathrm{hi}}$ & $-2.39 \pm 0.11^{\mathrm{k}}$ & $28.89 \pm 0.38^{\mathrm{hi}}$ \\
\hline 16 & $5858.38 \pm 104.53^{\mathrm{a}}$ & $1.32 \pm 0.13^{\mathrm{a}}$ & $64.64 \pm 0.31^{\mathrm{cd}}$ & $3.98 \pm 0.42^{\mathrm{c}}$ & $25.99 \pm 0.11^{\mathrm{a}-\mathrm{c}}$ \\
\hline 17 & $4386.32 \pm 91.88^{\mathrm{b}-\mathrm{e}}$ & $2.54 \pm 0.08^{\mathrm{c}-\mathrm{f}}$ & $62.53 \pm 0.71^{\mathrm{e}-\mathrm{g}}$ & $-0.53 \pm 0.09^{f-i}$ & $28.06 \pm 0.41^{\mathrm{fh}}$ \\
\hline 18 & $4071.82 \pm 90.64^{b}$ & $3.14 \pm 0.14^{\mathrm{g}}$ & $60.04 \pm 0.39^{i}$ & $-4.00 \pm 0.77^{1}$ & $29.95 \pm 0.71^{j}$ \\
\hline
\end{tabular}

a-1 Different letters in superscript of the same table column indicate on statistically significant difference between values, at level of significance of $p<0.05$ (based on post-hoc Tukey HSD test).

obtained for sample 1 . These results point that the addition of fresh and osmotically dehydrated wild garlic $(1.25 \%$ and $2.5 \%$ ) significantly statistically decreased hardness of biscuits while addition of oregano $(0.5$ and $1 \%)$ did not statistically significantly decreased hardness of biscuits. According to Piteira et al. [18] and Galla et al. [9] the higher levels of oregano and wild garlic, due to higher quantities of fiber, might resulted in lower binding of carbohydrates and further lesser breaking strength, and also in weakening gluten structure [19]. Osmotic treatment of wild garlic led to decrease of biscuit hardness in all corresponding samples, although not statistically significantly. Incorporation of molasses' composition via solid gain in osmotically dehydrated wild garlic has probably led to biscuits' hardness decrease.

Fracturability refers to the ease with which the biscuit will break. The minimum fracturability was obtained for sample 9, while maximum was obtained for sample 18 (Table 2). Values of fracturability statistically significantly increased with the addition of both fresh and osmodehydrated wild garlic, while adding oregano slightly increased fracturability. This indicates that fracturability increased with increasing fiber content in biscuits formulation (Table 2). Osmotic treatment of wild garlic led to increase of biscuit fracturability in all corresponding samples, again, not statistically significantly. As in the case of hardness, molasses solid gain of osmodehydrated wild garlic is probably responsible for this fracturability increase. Both texture analysis point at greater influence of wild garlic than oregano, due to higher share in dough formula.

The color characteristics of biscuits are important sensory characteristics of a product. This attributes are important in creating sensory expectations of consumers, which could affect their perception and acceptance of the product [13]. Instrumental analysis of biscuits color has shown that, with the increasing quantity of either fresh or osmotically dehydrated wild garlic and oregano addition, values of $L^{*}$ and $a^{*}$ have statistically significantly decreased, due to incorporation of colored ingredients to biscuits formulation and on more green coloured products, respectively. The highest $L^{*}(67.43)$ and $a^{*}$ value (7.68) was observed for samples 1 and 10, while the lowest $L^{*}$ value (60.04) and $a^{*}$ value (-4.00) was noticed for sample 18 , with the greatest shares of osmodehydrated wild garlic and oregano. Addition of osmodehydrated wild garlic has statistically significantly decreased biscuits' $L^{*}$ and $a^{*}$ values in comparison to the addition of fresh wild garlic, due to the color matters originating from molasses in solid gain of osmodehydrated wild garlic.

Statistically significant differences in values of $b^{*}$ were observed in samples with increasing share of wild garlic. 
The addition of oregano did not statistically significantly influenced values of $b^{*}$ like wild garlic. Addition of osmodehydrated wild garlic has slightly increased biscuits' $b^{*}$ values in comparison to the addition of fresh wild garlic.

Table 3 shows the results of chemical content analysis of all biscuits' samples. The addition of fresh and osmotically dehydrated wild garlic in molasses contributes to the increase of protein content of biscuits, however not statistically significantly. The increase is not prominent due to low level of wild garlic dry matter addition, but it indicates that protein level of fresh and osmotically dehydrated wild garlic in molasses is high. The biscuits' protein content results showed that process of wild garlic osmotic dehydration led to slight decrease of biscuits' protein content in comparison to the addition of fresh wild garlic, although solid gain from dehydrated wild garlic enriched biscuits formulation with favorable molasses chemical composition, that is rich in protein content [20], the explanation could be found in experimental plan. It defined amounts of addition of fresh and osmodeydrated wild garlic on dry matter basis, in effort to obtain comparable results in samples with used raw material of different water contents. Solid gain, as osmotic dehydration specificity, increased osmodehydrated wild garlic dry matter with molasses' composition that has lower dry matter protein content than wild garlic, hence lowering share of proteins in total dry matter of osmotically dehydrated wild garlic in comparison to the share of proteins in dry matter of fresh wild garlic. Starch and lipid content of biscuits has statistically insignificantly decreased with the addition of fresh and osmotically dehydrated wild garlic and oregano, due to incorporating small amount of non-starch and non-lipid compounds to biscuits formulation. Total sugars content in biscuits has statistically insignificantly decreased with the addition of fresh wild garlic and oregano, since these raw materials do not have total sugars in their compositions. With the addition of osmotically dehydrated wild garlic, total sugars content in biscuits has statistically insignificantly increased, due to high content of sucrose in molasses [20].

Biscuits' content of cellulose is statistically significantly increased with the addition of fresh and osmotically dehydrated wild garlic and oregano, where oregano contributed more to the cellulose content increase, due to its chemical composition. Cellulose content in biscuits with osmotically dehydrated wild garlic was statistically insignificantly lower than in case of biscuits with fresh wild garlic, from the reason explained at the protein content discussion.

Biscuits' ash content increased with the addition of fresh and osmotically dehydrated wild garlic, but decreased with addition of oregano, in both cases statistically insignificantly.

Table 3 Chemical content of biscuits with fresh and osmotically dehydrated wild garlic and oregano

\begin{tabular}{|c|c|c|c|c|c|c|}
\hline Sample num. & Proteins [\% d.m.] & Starch [\% d.m.] & Total sugars [\% d.m.] & Cellulose [\% d.m.] & Lipids [\% d.m.] & Ash [\% d.m.] \\
\hline 1 & $11.24 \pm 0.84^{\mathrm{a}}$ & $47.33 \pm 1.81^{\mathrm{a}}$ & $2.18 \pm 0.11^{\mathrm{a}}$ & $1.83 \pm 0.10^{\mathrm{a}}$ & $23.05 \pm 1.50^{\mathrm{a}}$ & $1.39 \pm 0.14^{\mathrm{a}}$ \\
\hline 2 & $11.35 \pm 0.71^{\mathrm{a}}$ & $47.11 \pm 1.47^{\mathrm{a}}$ & $2.17 \pm 0.14^{\mathrm{a}}$ & $1.98 \pm 0.12^{\mathrm{ab}}$ & $22.94 \pm 1.34^{\mathrm{a}}$ & $1.43 \pm 0.09^{\mathrm{a}}$ \\
\hline 3 & $11.45 \pm 0.81^{\mathrm{a}}$ & $46.89 \pm 1.90^{\mathrm{a}}$ & $2.16 \pm 0.09^{\mathrm{a}}$ & $2.12 \pm 0.09^{\mathrm{a}-\mathrm{c}}$ & $22.83 \pm 1.71^{\mathrm{a}}$ & $1.46 \pm 0.11^{\mathrm{a}}$ \\
\hline 4 & $11.16 \pm 0.76^{\mathrm{a}}$ & $47.01 \pm 1.45^{\mathrm{a}}$ & $2.16 \pm 0.07^{\mathrm{a}}$ & $2.49 \pm 0.19^{\mathrm{b}-\mathrm{d}}$ & $22.89 \pm 1.41^{\mathrm{a}}$ & $1.38 \pm 0.10^{\mathrm{a}}$ \\
\hline 5 & $11.27 \pm 0.61^{\mathrm{a}}$ & $46.80 \pm 1.26^{\mathrm{a}}$ & $2.15 \pm 0.06^{\mathrm{a}}$ & $2.63 \pm 0.10^{\mathrm{c}-\mathrm{e}}$ & $22.79 \pm 0.96^{\mathrm{a}}$ & $1.42 \pm 0.16^{\mathrm{a}}$ \\
\hline 6 & $11.38 \pm 0.59^{\mathrm{a}}$ & $46.58 \pm 1.51^{\mathrm{a}}$ & $2.14 \pm 0.08^{\mathrm{a}}$ & $2.77 \pm 0.11^{\mathrm{d}-\mathrm{f}}$ & $22.68 \pm 1.15^{\mathrm{a}}$ & $1.45 \pm 0.11^{\mathrm{a}}$ \\
\hline 7 & $11.09 \pm 0.69^{\mathrm{a}}$ & $46.70 \pm 1.77^{\mathrm{a}}$ & $2.15 \pm 0.16^{\mathrm{a}}$ & $3.14 \pm 0.16^{\mathrm{e}-\mathrm{g}}$ & $22.74 \pm 1.20^{\mathrm{a}}$ & $1.37 \pm 0.09^{\mathrm{a}}$ \\
\hline 8 & $11.20 \pm 0.78^{\mathrm{a}}$ & $46.49 \pm 1.69^{\mathrm{a}}$ & $2.14 \pm 0.09^{\mathrm{a}}$ & $3.27 \pm 0.29^{\mathrm{fg}}$ & $22.64 \pm 1.69^{\mathrm{a}}$ & $1.41 \pm 0.08^{\mathrm{a}}$ \\
\hline 9 & $11.30 \pm 0.59^{\mathrm{a}}$ & $46.27 \pm 1.50^{\mathrm{a}}$ & $2.13 \pm 0.08^{\mathrm{a}}$ & $3.41 \pm 0.18^{\mathrm{g}}$ & $22.53 \pm 1.48^{\mathrm{a}}$ & $1.45 \pm 0.09^{\mathrm{a}}$ \\
\hline 10 & $11.24 \pm 0.84^{\mathrm{a}}$ & $47.33 \pm 1.81^{\mathrm{a}}$ & $2.18 \pm 0.11^{\mathrm{a}}$ & $1.83 \pm 0.10^{\mathrm{a}}$ & $23.05 \pm 1.50^{\mathrm{a}}$ & $1.39 \pm 0.14^{\mathrm{a}}$ \\
\hline 11 & $11.30 \pm 0.79^{\mathrm{a}}$ & $47.10 \pm 2.04^{\mathrm{a}}$ & $2.21 \pm 0.12^{\mathrm{a}}$ & $1.93 \pm 0.14^{\mathrm{a}}$ & $22.93 \pm 0.98^{\mathrm{a}}$ & $1.42 \pm 0.09^{\mathrm{a}}$ \\
\hline 12 & $11.36 \pm 0.99^{\mathrm{a}}$ & $46.88 \pm 2.79^{\mathrm{a}}$ & $2.25 \pm 0.09^{\mathrm{a}}$ & $2.02 \pm 0.19^{\mathrm{ab}}$ & $22.84 \pm 1.39^{\mathrm{a}}$ & $1.47 \pm 0.10^{\mathrm{a}}$ \\
\hline 13 & $11.16 \pm 0.76^{\mathrm{a}}$ & $47.01 \pm 1.45^{\mathrm{a}}$ & $2.16 \pm 0.07^{\mathrm{a}}$ & $2.49 \pm 0.19^{\mathrm{b}-\mathrm{d}}$ & $22.90 \pm 1.41^{\mathrm{a}}$ & $1.38 \pm 0.10^{\mathrm{a}}$ \\
\hline 14 & $11.23 \pm 0.59^{\mathrm{a}}$ & $46.82 \pm 2.06^{\mathrm{a}}$ & $2.20 \pm 0.16^{\mathrm{a}}$ & $2.58 \pm 0.09^{\mathrm{cd}}$ & $22.78 \pm 1.76^{\mathrm{a}}$ & $1.42 \pm 0.11^{\mathrm{a}}$ \\
\hline 15 & $11.29 \pm 0.62^{\mathrm{a}}$ & $46.57 \pm 2.59^{\mathrm{a}}$ & $2.24 \pm 0.19^{\mathrm{a}}$ & $2.67 \pm 0.18^{\mathrm{de}}$ & $22.67 \pm 1.59^{\mathrm{a}}$ & $1.46 \pm 0.05^{\mathrm{a}}$ \\
\hline 16 & $11.09 \pm 0.69^{\mathrm{a}}$ & $46.70 \pm 1.77^{\mathrm{a}}$ & $2.15 \pm 0.16^{\mathrm{a}}$ & $3.14 \pm 0.16^{\mathrm{e}-\mathrm{g}}$ & $22.73 \pm 1.20^{\mathrm{a}}$ & $1.37 \pm 0.09^{\mathrm{a}}$ \\
\hline 17 & $11.15 \pm 0.99^{\mathrm{a}}$ & $46.47 \pm 1.87^{\mathrm{a}}$ & $2.19 \pm 0.19^{\mathrm{a}}$ & $3.23 \pm 0.27^{\mathrm{fg}}$ & $22.65 \pm 1.64^{\mathrm{a}}$ & $1.41 \pm 0.10^{\mathrm{a}}$ \\
\hline 18 & $11.22 \pm 0.87^{\mathrm{a}}$ & $46.28 \pm 1.94^{\mathrm{a}}$ & $2.22 \pm 0.10^{\mathrm{a}}$ & $3.32 \pm 0.19^{\mathrm{g}}$ & $22.54 \pm 1.49^{\mathrm{a}}$ & $1.45 \pm 0.06^{\mathrm{a}}$ \\
\hline
\end{tabular}

a-g Different letters in superscript of the same table row indicate on statistically significant difference between values, at level of significance of $p<0.05$ (based on post-hoc Tukey HSD test). 
Table 4 shows the results of mineral content analysis of all biscuits' samples. Mineral content of biscuits is significantly affected by the addition of oregano, fresh wild garlic and specially by osmotically dehydrated wild garlic to biscuits formulation, since osmotic dehydration in molasses enriches dehydrating material with increase of numerous mineral matters [21].

Zn biscuits content statistically significantly increased with the addition of both fresh and osmotically dehydrated wild garlic, and also by the addition of oregano. There is also statistically significant difference between $\mathrm{Zn}$ contents of biscuits with fresh and osmotically dehydrated wild garlic, indicating that osmotic dehydration process statistically significantly increased $\mathrm{Zn}$ content of biscuits. Due to the additions to the biscuits' formulation that are rich in $\mathrm{Zn}$ content $[2,22]$, cumulative increase of $\mathrm{Zn}$ content in sample 18 in comparison to the sample 1 was $27.75 \%$. The same as for $\mathrm{Zn}$ biscuits content, $\mathrm{Cu}$ biscuits content was, statistically significantly affected by the addition of both fresh and osmotically dehydrated wild garlic. $\mathrm{Cu}$ content of biscuits was increased with the increasing content of wild garlic addition in the formulation, in amount of $36.76 \%$, for maximal addition of osmodehydrated wild garlic. The same as in case of $\mathrm{Zn}$, osmotic dehydration process statistically significantly increased $\mathrm{Cu}$ contents of biscuits. Oregano did not statistically significantly increase $\mathrm{Cu}$ content of biscuits.
Mg biscuits content statistically significantly increased with the addition of wild garlic, since it is rich source of $\mathrm{Mg}$ [2]. Addition of $2.5 \%$ of fresh wild garlic increased $\mathrm{Mg}$ biscuit content for $11.05 \%$. The addition of oregano did not statistically significantly increase $\mathrm{Mg}$ content of biscuits, while process of osmotic dehydration statistically insignificantly decreased $\mathrm{Mg}$ content of biscuits. The same as for Mg biscuits content, the addition of wild garlic and oregano affected the increase of Ca biscuits content, statistically significantly and insignificantly, respectively. The cumulative increase of $\mathrm{Ca}$ biscuits content was $125.07 \%$, for the sample 9 in comparison to the sample 1 . Process of osmotic dehydration statistically significantly decreased Ca content of biscuits. Fe content of biscuits was statistically significantly increased with both additions of wild garlic and oregano. The same as in case of $\mathrm{Zn}$ and $\mathrm{Cu}$, osmotic dehydration process statistically significantly increased $\mathrm{Fe}$ contents of biscuits. Increase of Fe biscuits content in sample 18 was $49.69 \%$ in comparison to the sample 1, indicating on high Fe content of added raw materials to the biscuits' formulation [2, 21, 22]. $\mathrm{K}$ content of biscuits was statistically significantly increased with additions of both wild garlic and oregano, however osmotic dehydration did not contributed to the increased biscuits $\mathrm{K}$ content. The addition of wild garlic and oregano in biscuits improves mineral status in products and it is positively

Table 4 Mineral content of biscuits with fresh and osmotically dehydrated wild garlic and oregano (in [mg/kg])

\begin{tabular}{|c|c|c|c|c|c|c|}
\hline Sample num. & $\mathrm{Zn}$ & $\mathrm{Cu}$ & $\mathrm{Mg}$ & $\mathrm{Ca}$ & $\mathrm{Fe}$ & $\mathrm{K}$ \\
\hline 1 & $15.10 \pm 0.25^{\mathrm{a}}$ & $2.53 \pm 0.08^{\mathrm{a}}$ & $837.90 \pm 17.70^{\mathrm{a}}$ & $264.39 \pm 16.99^{\mathrm{a}}$ & $61.93 \pm 1.69^{\mathrm{a}}$ & $3.02 \pm 0.09^{\mathrm{a}}$ \\
\hline 2 & $16.65 \pm 0.35^{\mathrm{bc}}$ & $2.73 \pm 0.07^{\mathrm{a}-\mathrm{f}}$ & $880.19 \pm 20.80^{a-e}$ & $404.40 \pm 21.51^{\mathrm{e}-\mathrm{g}}$ & $70.70 \pm 0.99^{\mathrm{bc}}$ & $3.17 \pm 0.03^{\mathrm{a}-\mathrm{d}}$ \\
\hline 3 & $17.85 \pm 0.47^{\mathrm{de}}$ & $3.00 \pm 0.17^{\mathrm{c}-\mathrm{h}}$ & $921.69 \pm 24.18^{\mathrm{c}-\mathrm{e}}$ & $535.63 \pm 19.59^{\mathrm{ij}}$ & $78.49 \pm 1.15^{\mathrm{de}}$ & $3.32 \pm 0.06^{\mathrm{c}-\mathrm{f}}$ \\
\hline 4 & $15.31 \pm 0.18^{\mathrm{a}}$ & $2.55 \pm 0.07^{\mathrm{a}}$ & $839.47 \pm 20.70^{\mathrm{a}}$ & $288.43 \pm 20.91^{\mathrm{ab}}$ & $62.71 \pm 2.00^{\mathrm{a}}$ & $3.11 \pm 0.04^{\mathrm{ab}}$ \\
\hline 5 & $16.77 \pm 0.20^{\mathrm{bc}}$ & $2.72 \pm 0.09^{\mathrm{a}-\mathrm{e}}$ & $882.90 \pm 17.73^{\mathrm{a}-\mathrm{e}}$ & $440.61 \pm 23.54^{\mathrm{f}-\mathrm{h}}$ & $71.13 \pm 1.59^{\mathrm{bc}}$ & $3.26 \pm 0.06^{\mathrm{b}-\mathrm{e}}$ \\
\hline 6 & $18.15 \pm 0.21^{\mathrm{e}}$ & $3.12 \pm 0.19^{f-j}$ & $926.49 \pm 29.40^{\mathrm{de}}$ & $559.09 \pm 11.73^{j}$ & $79.53 \pm 0.69^{\mathrm{e}}$ & $3.41 \pm 0.07^{\mathrm{ef}}$ \\
\hline 7 & $15.52 \pm 0.29^{a}$ & $2.61 \pm 0.03^{\mathrm{a}-\mathrm{c}}$ & $840.92 \pm 17.16^{\mathrm{a}}$ & $307.23 \pm 16.69^{\mathrm{a}-\mathrm{c}}$ & $63.36 \pm 1.01^{\mathrm{a}}$ & $3.20 \pm 0.05^{\mathrm{a}-\mathrm{d}}$ \\
\hline 8 & $16.98 \pm 0.34^{\mathrm{bc}}$ & $2.85 \pm 0.08^{\mathrm{a}-\mathrm{g}}$ & $887.85 \pm 19.96^{\mathrm{a}-\mathrm{e}}$ & $485.30 \pm 20.93^{\mathrm{hi}}$ & $72.08 \pm 2.00^{\mathrm{bc}}$ & $3.35 \pm 0.07^{\mathrm{d}-\mathrm{f}}$ \\
\hline 9 & $18.26 \pm 0.19^{\mathrm{e}}$ & $3.26 \pm 0.14^{\mathrm{h}-\mathrm{j}}$ & $930.46 \pm 20.04^{\mathrm{e}}$ & $595.07 \pm 26.49^{j}$ & $80.06 \pm 2.09^{\mathrm{e}}$ & $3.49 \pm 0.08^{\mathrm{f}}$ \\
\hline 10 & $15.10 \pm 0.25^{\mathrm{a}}$ & $2.53 \pm 0.08^{\mathrm{a}}$ & $837.90 \pm 17.70^{\mathrm{a}}$ & $264.39 \pm 16.99^{\mathrm{a}}$ & $61.93 \pm 1.69^{\mathrm{a}}$ & $3.02 \pm 0.09^{\mathrm{a}}$ \\
\hline 11 & $16.93 \pm 0.07^{\mathrm{bc}}$ & $3.00 \pm 0.13^{\mathrm{c}-\mathrm{h}}$ & $869.15 \pm 20.83^{\mathrm{a}-\mathrm{e}}$ & $351.61 \pm 15.00^{c-e}$ & $74.71 \pm 1.44^{\mathrm{bc}}$ & $3.16 \pm 0.04^{\mathrm{a}-\mathrm{c}}$ \\
\hline 12 & $18.34 \pm 0.39^{\mathrm{e}}$ & $3.46 \pm 0.11^{\mathrm{i}-\mathrm{k}}$ & $907.51 \pm 23.18^{\mathrm{b}-\mathrm{e}}$ & $434.73 \pm 18.65^{\mathrm{f}-\mathrm{h}}$ & $90.92 \pm 2.08^{\mathrm{e}}$ & $3.29 \pm 0.06^{\mathrm{b}-\mathrm{e}}$ \\
\hline 13 & $15.31 \pm 0.18^{\mathrm{a}}$ & $2.55 \pm 0.07^{\mathrm{a}}$ & $839.47 \pm 20.70^{\mathrm{a}}$ & $288.43 \pm 20.91^{\mathrm{ab}}$ & $62.71 \pm 2.00^{\mathrm{a}}$ & $3.11 \pm 0.04^{\mathrm{ab}}$ \\
\hline 14 & $17.16 \pm 0.11^{\mathrm{b}-\mathrm{d}}$ & $3.09 \pm 0.12^{\mathrm{e}-\mathrm{i}}$ & $881.33 \pm 7.99^{\mathrm{a}-\mathrm{e}}$ & $361.74 \pm 10.95^{\mathrm{c}-\mathrm{e}}$ & $75.07 \pm 1.59^{\mathrm{b}-\mathrm{d}}$ & $3.25 \pm 0.06^{\mathrm{b}-\mathrm{e}}$ \\
\hline 15 & $18.52 \pm 0.17^{\mathrm{ef}}$ & $3.51 \pm 0.24^{\mathrm{jk}}$ & $909.16 \pm 27.16^{\mathrm{b}-\mathrm{e}}$ & $460.22 \pm 12.70^{\mathrm{gh}}$ & $92.08 \pm 1.83^{\mathrm{ef}}$ & $3.40 \pm 0.04^{\mathrm{ef}}$ \\
\hline 16 & $15.52 \pm 0.29^{\mathrm{a}}$ & $2.61 \pm 0.03^{\mathrm{a}-\mathrm{c}}$ & $840.92 \pm 17.16^{\mathrm{a}}$ & $307.23 \pm 16.69^{\mathrm{a}-\mathrm{c}}$ & $63.36 \pm 1.01^{\mathrm{a}}$ & $3.20 \pm 0.05^{\mathrm{a}-\mathrm{e}}$ \\
\hline 17 & $17.27 \pm 0.20^{\mathrm{cd}}$ & $3.17 \pm 0.11^{\mathrm{g}-\mathrm{j}}$ & $884.71 \pm 9.82^{\mathrm{a}-\mathrm{e}}$ & $390.71 \pm 20.61^{\mathrm{d}-\mathrm{f}}$ & $75.70 \pm 1.19^{\mathrm{cd}}$ & $3.35 \pm 0.08^{\mathrm{d}-\mathrm{f}}$ \\
\hline 18 & $19.29 \pm 0.33^{f}$ & $3.72 \pm 0.23^{\mathrm{k}}$ & $915.36 \pm 19.13^{\mathrm{b}-\mathrm{e}}$ & $487.93 \pm 24.51^{\mathrm{hi}}$ & $92.70 \pm 2.20^{\mathrm{f}}$ & $3.50 \pm 0.06^{\mathrm{f}}$ \\
\hline
\end{tabular}

a-k Different letters in superscript of the same table row indicate on statistically significant difference between values, at level of significance of $p<0.05$ (based on post-hoc Tukey HSD test). 
contributing to recommended daily intakes [23], due to high $\mathrm{Fe}$ and $\mathrm{Ca}$ contents, especially, for elder consumers.

Response surface methodology is used for developing mathematical models of biscuits quality parameters in dependence of added fresh or osmotically dehydrated wild garlic and oregano, Table S1. Based on ANOVA testing of analyzed responses (biscuits' quality parameters) in Table S1, it can be seen that quantity of fresh wild garlic and quantity of oregano statistically significantly affected both texture instrumental analysis responses of hardness and fracturability. In the case of osmodehydrated wild garlic, quantity of osmotically dehydrated wild garlic statistically significantly affected both texture instrumental analysis responses of hardness and fracturability, while fracturability was also statistically significantly affected by quantity of oregano. Both linear and quadratic SOP terms for quantity of fresh and osmodehydrated wild garlic statistically significantly contributed to formation of models for both texture responses. Linear SOP term for quantity of oregano statistically significantly contributed to formation of models for both texture responses, while cross product was statistically significant for mathematical model of fracturability in case of fresh wild garlic. Linear SOP term for quantity of oregano and cross product were statistically significant for mathematical model of fracturability in case of osmodehydrated wild garlic. Residual variances, as a measure of deviation of mathematical model from experimental data, for both texture responses, were not statistically significant, for both, fresh and osmodehydrated wild garlic, indicating that applied models for tested responses adequately represented biscuits quality parameters in dependence of different quantities of fresh or osmodehydrated wild garlic and oregano addition. Values of coefficient of determination $\left(R^{2}\right)$ which is defined as ratio of described variance with total system variance [24] were high (0.99 for all cases), which also point at good matching of SOP models with experimental values.

ANOVA test showed that values of all color instrumental analysis responses $\left(L^{*}, a^{*}\right.$ and $\left.b^{*}\right)$ were statistically significantly affected by both independent variables (quantity of fresh or osmodehydrated wild garlic and oregano), Table S1. Linear SOP terms for quantity wild garlic and oregano statistically significantly contributed to formation of models for all three color instrumental analysis responses in both cases, for fresh and osmodehydrated wild garlic. Quadratic SOP term for quantity of wild garlic was statistically significant in forming mathematical model for biscuit quality response $a^{*}$ in both cases for fresh and osmodehydrated wild garlic. Cross product was statistically significant for mathematical model of $a^{*}$ in case of fresh wild garlic. Residual variances were not statistically significant for color instrumental analysis responses in all cases for both fresh and osmodehydrated wild garlic, along with high values of $R^{2}$ (ranging from 0.98 to 0.99 ), indicating on good fitting of proposed color instrumental analysis responses models with experimental data.

The same as in case of color instrumental analysis responses, ANOVA test showed that values of all chemical content responses (proteins, starch, total sugars, cellulose, lipids, ash) were statistically significantly affected by both independent variables, in both cases of fresh and osmodehydrated wild garlic, Table S1. All linear SOP terms for quantity of wild garlic and oregano statistically significantly contributed to formation of models for all six chemical content responses, the same in cases of fresh and osmodehydrated wild garlic. Residual variances were not statistically significant for all chemical content responses, for both fresh and osmodehydrated wild garlic, and all values of $R^{2}$ were higher than 0.99 , indicating at good matching of all SOP models with experimental values.

ANOVA test showed that values of six mineral content responses ( $\mathrm{Zn}, \mathrm{Cu}, \mathrm{Mg}, \mathrm{Ca}, \mathrm{Fe}$ and $\mathrm{K}$ ) were statistically significantly affected by both independent variables, for both fresh and osmodehydrated wild garlic, except for $\mathrm{Mg}$ in case of osmodehydrated wild garlic, which was statistically significantly affected only by quantity of wild garlic, Table S1. Linear SOP terms for quantity of either fresh or osmodehydrated wild garlic and oregano statistically significantly contributed to formation of models for all six mineral content responses, except for $\mathrm{Mg}$ in case of osmodehydrated wild garlic.

Quadratic SOP term for fresh wild garlic quantity and cross product were statistically significant for $\mathrm{Cu}$ content model, and cross product was statistically significant for $\mathrm{Mg}$ content model. In case of osmodehydrated wild garlic, quadratic SOP term for wild garlic quantity for Fe content model, and cross product for $\mathrm{K}$ content model were statistically significant. Residual variances, again as in previous cases, were not statistically significant for all mineral content responses and, as in case of chemical content, all values of $R^{2}$ were higher than 0.99 , for both fresh and osmodehydrated wild garlic.

Tables S2 and S3 show regression coefficients of seventeen second order polynomial models of biscuits' quality parameters with added fresh and osmodehydrated wild garlic, respectively.

Statistical significance of individual coefficients that can be used for completing quadratic equations that 
describe models of quality parameters of biscuits, are marked. Based on these equations and known quantities of fresh or osmodehydrated wild garlic and oregano addition, values of desired responses (seventeen biscuits quality parameters) can be calculated, allowing prediction and adjustment of final product quality.

\section{Conclusion}

From presented results it can be concluded that addition of osmodehydrated wild garlic to biscuit dough formulation has provided better biscuits texture analysis results and changed color characteristics in comparison to the fresh wild garlic addition. Proteins, total sugars, cellulose and ash content of biscuits with added fresh or osmotically dehydrated wild garlic and oregano are increased in comparison to the biscuits with basic formulation. All tested mineral compounds content in biscuit samples increased with the addition of wild garlic and oregano. Addition of osmodehydrated wild garlic had provided higher $\mathrm{Zn}, \mathrm{Cu}$ and Fe biscuits' content in comparison to the addition of fresh wild garlic. The best essential minerals elements

\section{References}

[1] Ivanova, A., Mikhova, B., Najdenski, H., Tsvetkova, I., Kostova, I. "Chemical composition and antimicrobial activity of wild garlic Allium ursinum of Bulgarian origin", Natural Product Communication, 4(8), pp. 1059-1062, 2009. [online] Available at: https://www.ncbi.nlm.nih.gov/pubmed/19768983 [Accessed: 08 October 2018]

[2] Piątkowska, E., Kopeć, A., Leszczyńska, T. "Basic Chemical Composition, Content of Micro- and Macroelements and Antioxidant Activity of Different Varieties of Garlic's Leaves Polish Origin", Żywność. Nauka. Technologia. Jakość, 1(98), pp. 181-192, 2015. https://doi.org/10.15193/zntj/2015/98/014

[3] Black, C., Haughey, A. C., Chevallier, O. P., Galvin-King, P., Elliott, C. T. "A comprehensive strategy to detect the fraudulent adulteration of herbs: The oregano approach", Food Chemistry, 210, pp. 551-557, 2016.

https://doi.org/10.1016/j.foodchem.2016.05.004

[4] Lacerda, E. C. Q., Bauer, L. C., Oliveira, J. S., Silva, F. F., Carvalho, S. A., Macedo, M. S., de Souza, N. E., Simionato, J. I. "Effect of the dietary inclusion of dried oregano (Origanum vulgare L.) on the characteristics of milk from Holstein $\times$ Zebu cows", Animal Feed Science and Technology, 192, pp. 101-105, 2014. https://doi.org/10.1016/j.anifeedsci.2014.03.007

[5] El-Aouar, Â. A., Azoubel, P. M., Barbosa Jr., J. L., Murr, F. E. X. "Influence of the osmotic agent on the osmotic dehydration of papaya (Carica papaya L.)", Journal of Food Engineering, 75(2), pp. 267-274, 2006.

https://doi.org/10.1016/j.jfoodeng.2005.04.016 (maximum of $\mathrm{Zn}, \mathrm{Cu}, \mathrm{Mg}, \mathrm{Ca}$, Fe and $\mathrm{K}$ 19.29; 3.72; 915.36; $487.93 ; 92.70$ and $3.50 \mathrm{mg} / 100 \mathrm{~g}$; respectively) were experienced with sample 18 with maximum addition of osmodehydrated wild garlic and oregano $(2.5 \%$ and $1 \%$, respectively). The RSM well described mathematical models of biscuits' sixteen quality parameters in dependence of added fresh or osmodehydrated wild garlic and oregano, which all were statistically significant, while predicted and observed responses corresponded very well, allowing good prediction of biscuits quality parameters. In effort of obtaining new types of products, new application of known ingredients is proposed, allowing sugar beet molasses' rich nutrient content incorporation in wheat products formulation, while obtained biscuits with osmodehydrated wild garlic presented improved biscuits quality parameters in comparison to the biscuits with fresh wild garlic.

\section{Acknowledgement}

These results are part of the project supported by the Ministry of Education and Science of the Republic of Serbia, TR 31055 and III 46005.

[6] Koprivica, G. B., Mišljenović, N. M., Lević, L. B., Pribiš, V. S. "Changes in Nutritive and Textural Quality of Apple Osmodehydrated in Sugar Beet Molasses and Saccharose Solutions", Acta Periodica Technologica, 40, pp. 35-46, 2009. [online] Available at: https://scindeks-clanci.ceon.rs/data/pdf/1450-7188/2009/145071880940035K.pdf [Accessed: 08 October 2018]

[7] Tortoe, C. "A review of osmodehydration for food industry", African Journal of Food Science, 4(6), pp. 303-324, 2010. [online] Available at: https://academicjournals.org/article/article1380724248_Tortoe. pdf [Accessed: 08 October 2018]

[8] Dauda, A. O., Abiodun, O. A., Arise, A. K., Oyeyinka, S. A. "Nutritional and consumers acceptance of biscuit made from wheat flour fortified with partially defatted groundnut paste", LWT - Food Science and Technology, 90, pp. 265-269, 2018.

https://doi.org/10.1016/j.lwt.2017.12.039

[9] Galla, N. R., Pamidighantam, P. R., Karakala, B., Gurusiddaiah, M. R., Akula, S. "Nutritional, textural and sensory quality of biscuits supplemented with spinach (Spinacia oleracea L.)", International Journal of Gastronomy and Food Science, 7, pp. 20-26, 2017. https://doi.org/10.1016/j.ijgfs.2016.12.003

[10] Filipović, J., Ahmetxhekaj, S., Filipović, V., Košutić, M. "Spelt pasta with increased content of functional components", Chemical Industry and Chemical Engineering Quaterly, 23(3), pp. 349-356, 2017. https://doi.org/10.2298/CICEQ160208049F

[11] Pasqualone, A., Bianco, A. M., Paradiso, V. M., Summo, C., Gambacorta, G., Caponio, F. "Physico-chemical, sensory and volatile profiles of biscuits enriched with grape marc extract", Food Research International, 65(C), pp. 385-393, 2014. https://doi.org/10.1016/j.foodres.2014.07.014 
[12] AACC "AACC 10-50D: Baking Quality of Cookie Flour", In: Approved Methods of the American Association of Cereal Chemists, 10th ed., AACC International, St. Paul, MN, USA, 2000.

[13] Filipović, J., Pezo, L., Filipović, V., Brkljača, J., Krulj, J. "The effects of $\omega-3$ fatty acids and inulin addition to spelt pasta quality", LWT Food Science and Technology, 63(1), pp. 43-51, 2015. https://doi.org/10.1016/j.lwt.2015.03.082

[14] Horwitz, W. "Official Methods of Analysis of AOAC International", 17th ed., AOAC International, Gaithersburg, MD., USA, 2000.

[15] Box, G. E. P., Behnken, D. W. "Some New Three Level Designs for the Study of Quantitative Variables", Technometrics, 2(4), pp. 455-475, 1960. [online] Available at: https://www.jstor.org/ stable/pdf/1266454.pdf?refreqid=excelsior\%3Ae3aab395efd04e51848ce587e7105903 [Accessed: 08 October 2018]

[16] StatSoft Inc. "STATISTICA Data Analysis Software System, (version 10)", 2010. [computer program] Available at: http://www.statsoft.com [Accessed: 08 October 2018]

[17] Singh, P., Singh, R., Jha, A., Rasane, P., Gautam, A. K. "Optimization of a process for high fibre and high protein biscuit", Journal of Food Science and Technology, 52(3), pp. 1394-1403, 2015. https://doi.org/10.1007/s13197-013-1139-z

[18] Piteira, M. F., Maia, J. M., Raymundo, A., Sousa, I. "Extensional flow behaviour of natural fibre-filled dough and its relationship with structure and properties", Journal of Non-Newtonian Fluid Mechanics, 137(1-3), pp. 72-80, 2006. https://doi.org/10.1016/j.jnnfm.2006.03.008

[19] Filipović, J., Filipović, N., Filipović, V. "The Effects of Commercial Fibres on Frozen Bread Dough", Journal of the Serbian Chemical Society, 75(2), pp. 195-207, 2010. https://doi.org/10.2298/JSC1002195F
[20] Šarić, L. Ć., Filipčev, B. V., Šimurina, O. D., Plavšić, D. V., Šarić, B. M., Lazarević, J. M., Milovanović, I. L. "Sugar Beet Molasses: Properties and Applications in Osmotic Dehydration of Fruits and Vegetables", Food and Feed Research, 43(2), pp. 135-144, 2016. https://doi.org/10.5937/FFR1602135S

[21] Nićetin, M., Lević, L., Lončar, B., Filipović, V., Knežević, V., Kuljanin, T., Pezo, L. "Characterization of Fruit Yoghurt with Apple Cubes Osmodehydrated in Molasses", Journal of Hygienic Engineering and Design, 9, pp. 64-67, 2014. [online] Available at: http://www.jhed.mk/filemanager/JHED\%20Vol.\%209/03.\%20 FPP/03.\%20Ful1\%20paper\%20-\%20Milica\%20Nicetin.pdf [Accessed: 08 October 2018]

[22] Zaguła, G., Fabisiak, A., Bajcar, M., Czernicka, M., Saletnik, B., Puchalski, C. "Mineral components analysis of selected dried herbs", Econtechmod. An International Quarterly Journal, 5(2), pp. 121-124, 2016. [online] Available at: http://ena.lp.edu.ua/bitstream/ntb/33757/1/18-121-124.pdf [Accessed: 08 October 2018]

[23] Official Gazette of the Republic of Serbia "Regulation on Labelling and Marking of Packaged Foodstuffs", 2004 SI 4/2004, 2/2004, 48/2004, JP Službeni glasnik, Belgrade, Serbia, 2004.

[24] Madamba, P. S. "The Response Surface Methodology: An Application to Optimize Dehydration Operations of Selected Agricultural Crops", LWT - Food Science and Technology, 35(7), pp. 584-592, 2002. https://doi.org/10.1006/fstl.2002.0914 